複数の逸脱刺激または複数の標準刺激によるP300について

-P300の心理的意味に関する基礎的検討一

小嶋知幸(1) 加我君孝(2) 蔵内隆秀(3)

江戸川病院リルビリテーショコ科(1) 東京大学耳鼻科(2) 東芝病院耳鼻科(3)

[はじめに]

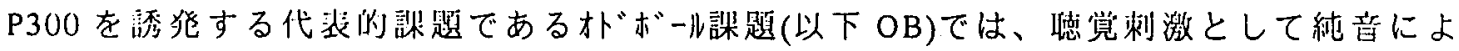
るトーンバーストが用いられることが多いが、言語音を用いても P300が誘発されることは吙ら れている。闻 OBによる誘犯反応は加算波形も類似しているか、言語音 OB は、純聓 $\mathrm{OB}$ とは異なるいくつかの特徵を持っていると考えられる。先ず第 1 に、純音 OB の場合には 特珠な被験者を除いて刺激に対応するテソプレートが脸内に存在しないのに対して、言語音 $\mathrm{OB}$ では刺激に対するテンプレートが脳内に存在する点、第 2 に刺激に対するテンプレートのない純音 $\mathrm{OB}$ に比べ、テンプレートのある言語音 OB は実験中の短期記憶への依存度が低いという点、そし

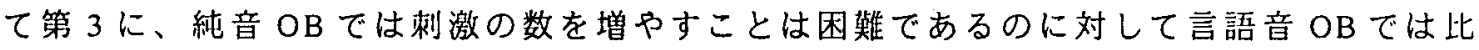
較的容易であるという点である。以上の言語音 OBにおける特性のうち、複数の刺激の使 用が可能である点を利用して、本研究では、(1)複数の刺激をカテゴリー化して晩脱刺激また は標準制激とした場合にP300 が出現するか、(2)P300が出現するとしたら、単一の逸脱 および栖準制激による OBに比べてどのような変化があるのか、(3)変化が得られたとし たらその事から $\mathrm{P} 300$ の心理的意味として何が言えるか、以上 3 点について検討したので 報告する。

[方 法]

I. 刺 激：日本語の音韻から 5 母音と力行の 5 音を選択し、成人男性の音声で録音した。 持続時間は、 $/ \mathrm{a} /(280 \mathrm{~ms}) 、 / \mathrm{i} /(310 \mathrm{~ms}) 、 / \mathrm{u} /(350 \mathrm{~ms}) 、 / \mathrm{e} /(300 \mathrm{~ms}) 、 / \mathrm{o} /(380 \mathrm{~ms}) 、 / \mathrm{ka} /(360 \mathrm{~ms}) 、$ $/ \mathrm{ki} /(350 \mathrm{~ms}) 、 / \mathrm{ku} /(370 \mathrm{~ms}) 、 / \mathrm{ke} /(380 \mathrm{~ms}) 、 / \mathrm{ko} /(400 \mathrm{~ms})$ である

II.実験条件：複数の刺激をがループ.化して逸脱刺激あるいは標準刺激とする OBを 4 条件 設定した。すなわち(1)逶脱刺激を/a/、標準刺激を/ka/とする 1 対 1 条件、(2)选脱刺激を/a/ 標準刺激を力行 5 音とする 1 対多条件、(3)逸脱刺激を 5 母音、標準制激を/ $\mathrm{ka} /$ とする多対 1 条件、(4)选脱刺激を 5 母音、標準刺激を力行 5 音とする多対多条件である。 4 条件とも刺 激呈示頻度は、选脱刺激全体で $20 \%$ 、標準刺激全体で $80 \%$ 。被験者に課された課題は逸 脱刺激に対するボ多押しである。

III. 対象：健常成人 10 名(男性 2 名、女性 8 名)、平均年龉 30 歳。 IV.記録条件：電気的に遮蔽された部屋で、被験者は安楽な椅子にて開眼し一点を注視し た状態で課題を遂行した。記録電極は 10/20 法により頭皮上 $\mathrm{Fz} 、 \mathrm{Cz} 、 \mathrm{Pz}$ に設置し、基準 電極は雨耳染速結とした。、日本光電製 MEB4208を用い、フイ多一を $0.5 \mathrm{~Hz} \sim 50 \mathrm{~Hz}$ 、刺激の音 圧を $80 \mathrm{~dB} \mathrm{HL}$ 、刺激間隔を 2 秒に設定した。刺激呈示前 $100 \mathrm{~ms}$ から刺激提示後 $900 \mathrm{~ms} の$

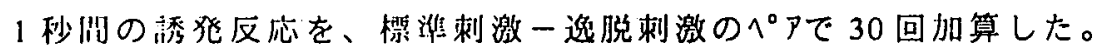

V.デー夕解析：得られた加算波形における、P300の潜洔および振幅、N1の潜時、ボ多押し の反応潜洔をそれそれ実験条件別、電極別に比較した。統計手法は繰り返し测定法による 分散分析を用いた。

[絬 果]

実験条作別の 10 人の被験者による誘発反応の総加算波形を図 1 に示す。 
(1)P300潜將：条件の主效果が優位であった (p<0.001)。条件別では条作 1(1 対 1)、条件 3 (多対 1)、条俳 2 (1 対多)、条件 4(多対多)の順に早かった。電極の主效果も優位であっ たが $(p<0.05)$ 、優位差を認める組み合わせは検出されなかった。(2)P300 振幅：条件の 主効果が優位であった $(p<0.05)$ 。条件別では、条件 1(1 対 1)、条件 3(多対 1)、条件: 2(1 対多)、条件 4(多対多)の順に大きかった。電極の主效果も優位であったが $(p<0.001)$ 、優

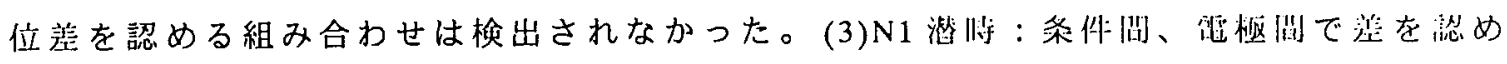
なかった。(4)木゙外师し反応：条件間で主效果を認めたが、優位差を認める組み合わせは 㭘出されなかった。

[考祭とまとめ]

(1)被数の刺激に対して、脳内で逸脱刺激と標準刺激という力テゴリー化が行われれば P 300 は出現する、(2)刺激のカテゴリー化のような、課題遂行中の作業記憶の消貿によって?300 の潜胕は延長し振幅は減少する、(3)适脱刺激に対する作業記憶の消賀か大きい場合(多

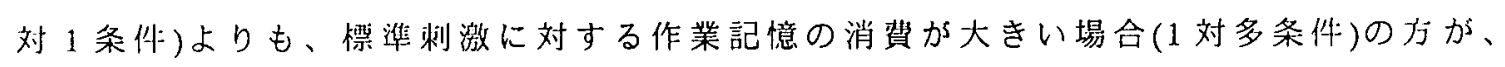

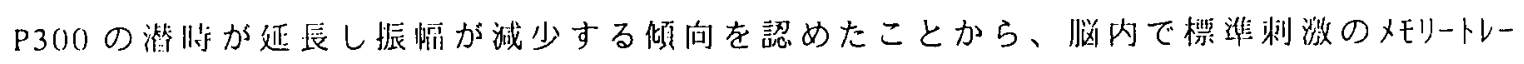
スが扸成されることがP300誘発の劝ニズムにかかわる重要な要因の1つであり、紧準刺

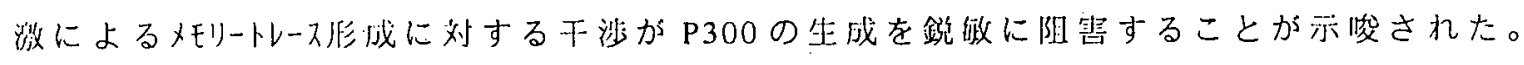

\section{条件別総加算波形 $(\mathrm{N}=\mathbf{1 0})$}
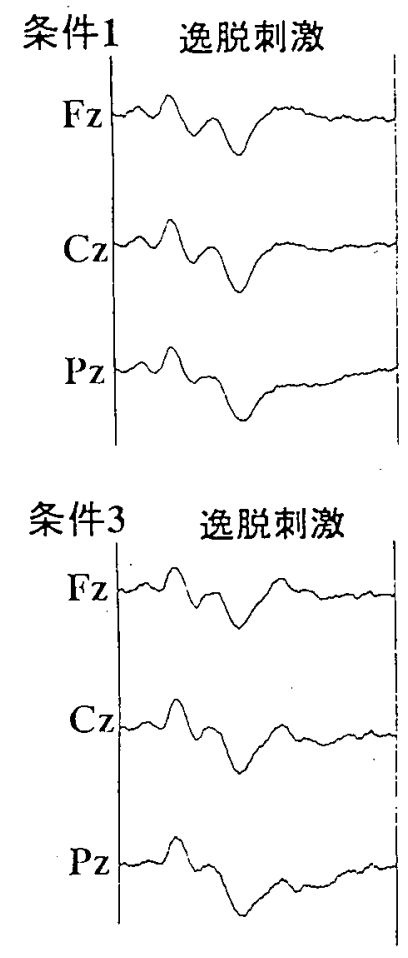

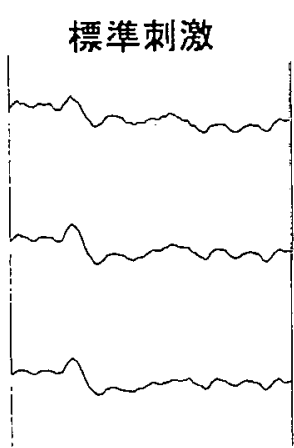

標準刺激

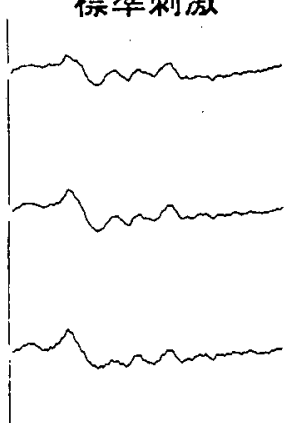

条件2 逸脱刺激
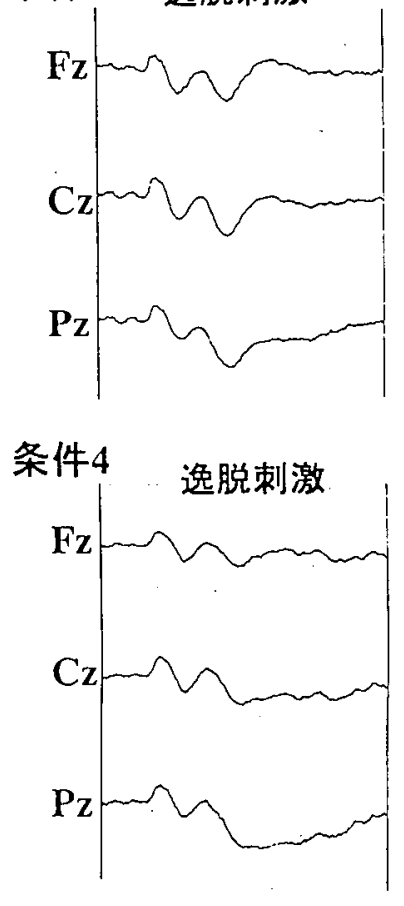

標準刺激

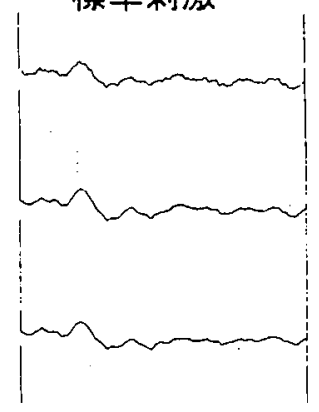

標準刺激

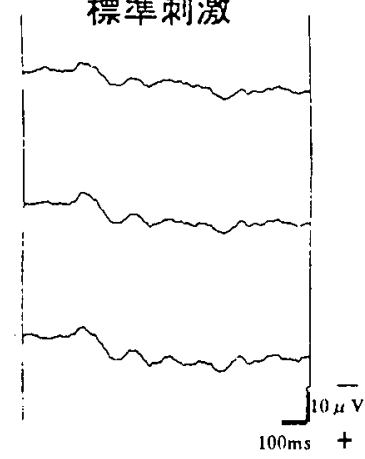

図 1 